\title{
THE PSYCHO-PEDAGOGICAL PROFILE OF A TUTOR IN E-LEARNING \\ Maria GOGA*
}

\section{Abstract:}

In a society based on knowledge, in a continuous economic social and educational changing, there is the need of qualified people to cope with the avalanche of new innovative ideas. The labour market in Europe and around the world increasingly requires highly trained and qualified personnel to meet the requirements of rapid technological change in almost all the areas of life. Teaching virtually is different that teaching face-to-face. In this article we make a summary of the research done within the context of the $\mathrm{PhD}$ thesis of the author which investigates this new type of learning and skills and it manages staff roles - tutors - and suggests in this regard a training module for this new profession. The research was performed with institutions from Romania and from other countries in Europe, U.S.A., and Asia.

Keywords: Tutor, E-learning, virtual community, initial and ongoing training

\section{Introduction}

In a society based on knowledge, in a continuous economic social and educational changing, there is the need of qualified people to cope with the avalanche of new innovative ideas. The labour market in Europe and around the world increasingly requires highly trained and qualified personnel to meet the requirements of rapid technological change in almost all the areas of life. The educational system is largely affected by the effervescence of technological transformations, providing novelty, accessibility and quality of learning. To ensure proper training for the staff, in a competitive and dynamic society, the educational system is required to adapt itself to the present realities.

Teacher training is seen in the context in which it is necessary to redefine the teaching/ learning methods by focusing on providing a qualitative psycho-pedagogical context, taking into account the market demands and the student's needs as well as the learning opportunities. The characteristics of the education that meets today's economic and social change focus on "flexibility,

* Maria Goga is online teacher at the IEC Institute, Griggs University, U.S.A. E-mail: goga.maria@yahoo.com 
creativity, ability to resolve problematic situations, technological literacy, searching skills, information processing and especially the willingness to continuously leam" (Singer et al, 2006, p. 237). The introduction of computer technology in education brings changes as far as the teaching is concerned, and leads to the usage of new methods, activities and resource types. E-learning is one of the learning systems and methods that encompasses such new activities in the educational process. This system is no longer a novelty for many of today's educators and it is being increasingly used. Actually, its implementation is a necessity for many students, and an answer to their educational needs. The teachers involved in this system (Salmon, 2000) consider there should be a detailed understanding of how it is organized, and also what underlying pedagogy, technology and knowledge can be used in such a system. To meet the educational challenges of these changes there is a need for a definition of the psycho-pedagogical profile of the people responsible in this process. In our case, the tutor is the one "responsible". He is known as the interface between the institution and students, a group animator and a guide for the student's leaming "(Levy, 1999). The tutor is a necessity in the electronic-based leaming, the success of an E-learning course depending on his activity (Palloff \& Pratt, 2007).

Sporadic initiatives on training teachers in universities for the roles of tutors is an important step in connecting the system to student-centred learning, a paradigm that underpins the e-learning system, but it does not satisfy the need for a sustained and consistent training of the tutors, those who are directly involved in the leaming process. Can the initial or continuing training in an organized and well defined way for the educators in E-leaming lead to a viable solution for a professional tutoring, as opposed to volunteering way, as (we will see that it is) done today in many academic centres in Romania? In this context the present article aims at analysing the role of the tutor, his competencies and the conditions of professionalization for this job, by investigating the current situation of the e-learning in Romania and also in the international context.

Literature review In the following paragraph we do a short literature survey of important ingredients of our research.

Role of the tutor (online teacher): Gunawardena (Gunawarda, 1992) suggests "The role of the teacher changes from a teacher controlling the content and process, to that of a facilitator whose primary role is to guide and support the learning process".

The competencies are defined by Spector and La Teja (Spector, 2001) as "Competence refers to state of being well qualified to perform an activity, task or job function". As noted by Brigitte Denis (Denis, 2004), some competencies are described by several authors, however "many of these scholars emphasize only one or two aspects of these competencies". As we see there is place for more research (from an integrated point of view) also in this area. 
For tutorial lessons, according to J. Duggleby (Duggleby, 2000), "the learners ask for clarification about the course content, or to know if their work is meeting the course requirements. They may need help organising their workload or planning their time". The tutor is the one who will meet the students needs in the tutorial meetings, synchronously or asynchronously, in every day or weekly.

O. Istrate (Matu, 2005) defines the evaluation as the activity of gathering, processing and interpreting the information regarding the quality of the learning outcomes and of the process that generated them. Instruments used for online evaluation, as Ryan (Ryan, 2005) notes "covers far more than the traditional multiple choice test. Systems now in place support a variety of objective tests that can involve the manipulation of textual, graphical or mathematical elements, the submission and commuting work and automated marking on assignments".

Communication of the tutor with online students is very important. One reason for this is given by Collinson, G. et all (Collison, 2005), that writes "guidance from a moderator (tutor) who can essentially "see" what's going on in a dialogue and light the way forward is essential for progress".

Adapting the course to different learning styles is essential for student leaming progress. As Theng \& Thimpley (Theng, 1998) noted "learning is important when a student is allowed to follow pathways of their own choice, at their own pace".

\section{Motivation and research}

In the e-learning literature, most of the time, different technical aspects are treated, while the psychological and pedagogical aspects have very little space (Mckenzie \& Peters, 2001). The space that it is allocated for them is very small compared with the one allocated to the technical details. Moreover, when these aspects are treated, the authors make general observations without entering into the specificity of the field into a great detail. Although the technology plays an important role, one should not forget that the psychological and pedagogical aspects make the learning process to be a success.

Different authors agree that there is no so much in depth research regarding the psycho-pedagogical aspects of the online tutors. For example, Garrison (Garrison, 2003) notes that "to date published research and guides consists of innumerable case studies and personal descriptions, but little in the way of rigorous research that leads to an in-depth understanding of e-learning in higher education". We can agree that there are many case studies presented in the literature, but research that views the psycho-pedagogical aspects of the educational process in e-leaming as a whole does not exist too much. One of the 
goals of this article is to fill this gap by presenting an investigative qualitative and quantitative work regarding the tutorial activity. Another innovative element is given by the fact that little research of this kind is conducted in Romania, taking into account the specificity of the e-learning process in this country (that was just started).

The psycho-pedagogical activity of the tutor is a relatively new reality in the Romanian educational system. If internationally there are concerns regarding the professional training of the tutors (Salmon, 2000), in Romania, they do not have a clear pedagogical profile and the Governmental Teaching Staff Statute (art. 53) does not define this job. This absence has negative effects for the work of the tutors, its activity currently being done more in conditions of volunteering and not in a professional way. Also, in Romania, currently there are no courses for the initial or ongoing formation of the tutors organized at a national level. Local existence of training programs and other initiatives do not replace the acute need for training courses at a national level. Through the work presented here, we want to fill this gap, by presenting the results of a qualitative and quantitative study made on different universities from Romania, regarding the psychological and pedagogical aspects involved in e-leaming. In this respect, another goal of this article is to present one of the first study regarding e-tutoring activity in Romania.

In this context of a need for the professionalization of the tutors in Romania, we propose the definition of a psycho-educational profile of the tutor in the e-learning system by formulating a general framework for the training of the tutors in the E-learning system. Thus, through this research we will identify the "essential pillars" that would be the basis of the tutor training. In this context we will try to develop a psycho-pedagogical training module. The module is based on models of psycho-pedagogical training of the tutors taken from the literature, and also from the basic elements of some international courses for the online training of the tutors and as well as on the results of the present research. This module is composed of four main sections: the pedagogical dimension, the psycho-social dimension, the management dimension and technical dimension. The four dimensions are derived from the core functions of the tutor as found in the literature, constituting the main elements that are necessary for the academic training of the tutors in the e-learning system.

\section{Research objectives}

The research included the following research objectives:

a) Analysis of recent challenges for the teaching profession, with particular emphasis on the tutors in e-learning;

b) Analysis of current situation in Romania and other countries regarding the tutor's academic activity in E-learning - from his perspective 
(where this leaming system is a main form of organization of leaming) and from the perspective of the students participating in this learning system;

c) Proposal for actual strategies of recognition and training of the tutor as a modern hypothesis of the modern teaching.

\section{Sampling}

In order to achieve the intended purpose, this study involved both tutors and students from universities in Romania and in different countries in Europe, America and Asia, trying to compare the experiences of the tutors from Romania with other tutors around the world. The sampling type used was the snowball method (De Vos, 2002). In this type of sampling key individuals were asked to provide a list of people who are / may be relevant to this research. Once the subjects identified (in our case, tutors and students), they at their tur will indicate further other names of tutors / students until an acceptable number of participants is accomplished. Thus we covered in our research a total of nine countries, including 16 faculties / departments, 97 tutors and 244 students.

Instirutions from Romania

Instimtions from other comatries

5N.SPA. Broheret

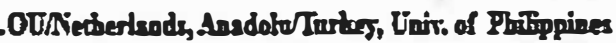

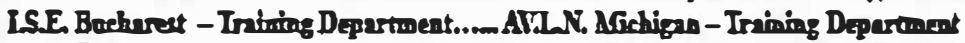

A.S.E Buchurest IIU Cabifornia, AIIASPhilippines, Uuir. North Carofins

Palinechnigne Bachnert Tmisonn Oda Finlaada, Mnribora/Stovenin

Figure 1. Institutions participating to the survey (Romania and other countries)

\section{Research methods and tools}

To gain a more complete overview of the work of the tutors in the e-learning system, both quantitative and qualitative methods were used including the following instruments: analysis of documents, questionnaire, individual interview, observation, case study,.

Analysis of documents. Comparative analysis of the curricula of two faculties (Faculty of Communication and Public Relations, National School of Bucharest and Faculty of Psychology, Open University Netherlands). This analysis intended to compare the two universities to identify common points and differences in the organization of their e-learning curriculum. Also, in the present research, we chose to compare two training courses for tutors. We compared the Pilot Program of the European Commission (ETT) at another one from the United States of America $(A V L N)$. We tried to identify similarities / 
differences between the two sets of courses regarding their leaming objectives, learning content, issues addressed, types of activities (teaching / learning) and assessment.

Questionnaire survey - sent to tutors. This questionnaire was intended to achieve an overall picture of the psycho-pedagogical activity of the tutors in Romania: identification of ups and downs of the existing tutorial work in Romania, together with a larger comparison of the situation of the tutorial work in Romania as compared with the work of other tutors from other geographical areas. This comparative research was intended to improve the educational system of e-leaming in Romania.

Questionnaire survey - to students. The questionnaire was sent to the students participating in online classes and DL from different universities in Romania, Slovenia and the Philippines. Most students participating in the survey belong to the Romanian universities, other countries (Slovenia and the Philippines) are in minority. 215 students have participated in the research, of which 96 and 119 medium for online DL. The questionnaire aims to identify key elements of the psycho-pedagogical activity of the tutors, viewed from the perspective of the students.

Individual interview regarding the role of the tutor - addressed to the tutors. The interviews were made with distance learning tutors from the following countries: Philippines (an interview AIIAS), Finland ( 2 interviews, Oulu University) and U.S. (an interview, Writing Center / University of North Carolina), Romania ( 2 interviews Polytechnic University of Bucharest, National School). The online Tutoring is a less explored topic. Often ideas are different from one university to another and from one country to another. Therefore, we considered it necessary to supplement the information obtained through questionnaires throughout this qualitative research regarding the role of the tutor.

Individual interview regarding the tutor training - addressed to the tutor. This interview is addressed to tutors and is complementary to the tutor questionnaire, detailing the aspects treated in the questionnaire. If in the quantitative research we tried to identify core aspects of tutor activity in Romania as compared to the international practices or as described in the literature, this interview concentrated on some specific aspects related to the tutorial work in various universities in Romania and other countries. Through this interview we tried to identify the elements that make the role of a tutor efficient, and also things that can be integrated into a training module for tutors.

Individual interview for students. The interview was aimed for the students in Romania and it tried to get a more detailed picture of the tutors' work, but from the perspective of the students participating in the courses.

Individual interview for decision makers regarding E-learning. A number of decision makers responsible for the e-leaming activities in Romania have provided answers to questions concerning the E-learning system covering the following issues: reasons for Romanian universities to adopt E-leaming, 
types of E-learning systems fitted for the Romanian educational system, pedagogical impact of the E-learning system on institutions in Romania, the pedagogical impact of the E-learning system on teachers in Romania, ways of involving decision-makers in the development of the E-learning in Romania.

Observations. Observations were made by the researcher of this study as participant in online courses and as non-participating observer in an online courses from AVLN and in DL/online courses from SNSPA and ISE. During the research we were able to observe the existing practice within the mentioned institutions, to make relevant observations and remarks.

Case Studies. The case studies sought to define the psycho-pedagogical profile of the tutors in E-learning. These studies are integrated into the chapter that present the results of the research and deal with the analysis and interpretation of the results in the thesis.

\section{Main conclusions}

This study allowed us to summarize the main findings related to the academic training of the tutors in the E-learning system. Through this research I was able to observe and analyse different aspects of psycho-pedagogical profiles of the tutor in some institutions with an e-learning program, in Romania and also other countries. Thus, the findings of this study are, we believe, relevant and useful for the purpose intended: the professionalization of the tutor.

The identity of the tutor is closely linked to the E-leaming environment, therefore, his training and professional development is seen through the emergence and implementation of this system. Since the subjects who participated in the research came from different institutions with different forms of E-learning, the tutor's identity, implicitly the method of training and professionalization of it, are different.

One of the objectives of this study was to propose concrete ways of recognizing the tutor as a modern hypothesis of the teaching profession. Thus, in order to achieve this goal, we have proposed for validation a psychopedagogical training module for tutors emerged from the literature. Through this module we wanted to create the basic parameters by which a tutor can be trained, and his activity to be recognized officially. During our investigation we found that the most of the elements that make up the module obtained from the results of the study are validated by the research results in the literature. First, there were addressed the issues related strictly to the e-learning with direct implications for the tutor's training, and later the roles and skills in the learning process were described. Based on the main functions of the tutor (pedagogical, psycho-social, managerial and technical) we have developed the framework of the module, which has the same names as the functions. This module is based 
on relevant literature and present research results and it can be used for professional tutor training. The conclusions that we will propose further will be presented in conjunction with the understanding of the urgent need for training tutors in an organized, professional environment. Based on the data provided by the participants in the inquiry (tutors, policy makers, students), we highlight the key elements related to the tutor training, focusing directly on the Romanian system of learning. Summarizing the main findings they are:

The e-learning system takes different forms from one country to another, from one university to another, depending on the needs and opportunities for students, and institutions. The forms of DL, ODL and blended learning are able to combine the traditional environment of learning with the online learning. On the one hand, they have created multiple and varied learning opportunities for adult learners, and on the other hand we wanted to preserve certain traditional elements, such as the evaluation of the examination centres, to provide a fuse for testing students' knowledge and coming face to face meetings to fill the moments of virtual social isolation. In Romania, although the possibility of using the Internet are reduced because of the infrastructure, students prefer this type of learning that is expressed by the form of Internetbased Distance Education. There are several types of forms of online learning, however, often the blended learning is preferred, a mixture of online courses with traditional courses, a form of "perverted" E-learning system.

The presence of the tutor in the E-learning system is a reality. The analysis of the implementation of the e-learning system in the countries participating in the research allowed the shaping of the concept of the tutor, of the skills and work done by him in the educational process. The term of the tutor has different meanings in Europe, America and Australia. A tutor with a teaching positions in Europe (which includes Romania) is the online teacher "(teacher online)" in America, "online lecturer (assistant online)" in Australia. The one who is called tutor in America and Australia is merely a "coach" (tutor) for students at individual or group level. Thus, the tutor is appointed tutor in the European context and is considered a teacher. In Romania, although the tutor is not present on the list of teachers in the university system (Teacher Statute, Art. 53), he acts as a teacher. According to the definition drawn from the results, a tutor is the teacher who mediates between the faculty / institution and students, supporting virtual dialogue, directing, motivating and evaluating students in learning. A tutor is a teacher, but until now, officially (Staff Teaching) is not regarded as such. For a tutor to be regarded as a teacher in the Romanian system of learning a reorganization of the way he is trained is necessary.

The roles of the tutor, considered the main participants in our study, are viewed as: facilitator, expert, mentor, counsellor and a moderator (Table 1). The other roles - such as the "coach" (advisor), "designer", manager, technician are secondary roles. It is interesting to see that this list of roles (which also includes the main and secondary roles) is similar to that found in the literature. 
Thus, the manner of grouping these functions could follow the model found in the literature of the field, respectively: the educational, psycho-social, managerial and technical. On this categorization depended both the shaping of the skills and how the training module for the academic training was developed as well.

Table 1. Roles attributed to the tutor with relevance for the Romanian Elearning system

\begin{tabular}{|c|c|c|c|c|c|}
\hline \multicolumn{4}{|c|}{$\begin{array}{l}\text { Roles drawn-from the qualitifive and quantitathe } \\
\text { research }\end{array}$} & \multicolumn{2}{|c|}{$\begin{array}{l}\text { Roles defined in the } \\
\text { literature }\end{array}$} \\
\hline \multicolumn{2}{|c|}{ Feading Role } & \multicolumn{2}{|c|}{ Secondary role } & \multirow[b]{2}{*}{ Functions } & \multirow[b]{2}{*}{ Roles } \\
\hline Eurctions & Roles & Functions & Roles & & \\
\hline Pedagogical & $\begin{array}{l}\text { Facilitator } \\
\text { * Expert }\end{array}$ & Pedagogical & $\begin{array}{l}\text { * Assessor } \\
\text { * Coach } \\
\text { * Designer } \\
\text { * Instructor }\end{array}$ & Pedagogical & $\begin{array}{l}\text { * Facilitator } \\
\text { * Coach } \\
\text { * Expert } \\
\text { * Instructor } \\
\text { * Assessor } \\
\text { * Designer }\end{array}$ \\
\hline Social & $\begin{array}{l}\text { * Mentor } \\
\text { * Advisor }\end{array}$ & & & Social & $\begin{array}{l}\text { * Mentor } \\
\text { * Advisor }\end{array}$ \\
\hline Managerial & Moderator & Managerial & * Manager & Managerial & $\begin{array}{l}\text { * Manager } \\
\text { * Moderator }\end{array}$ \\
\hline Technical & & & Technician & Technical & * Technician \\
\hline
\end{tabular}

The tutor's skills were systematized according to the three main sequences of a course (before the course, during the course and at the end of it) and its main functions (teaching, psycho-social, managerial and technical). The interviewed tutors pointed to a certain hierarchy of the skills. Thus, a main place is occupied by the psycho-social skills, and the lack of these may deepen the social barriers imposed by the E-learning system. On the same line there are the pedagogical ones, which, according to those investigated, already exist, assuming that the tutor does not start his professional activity without them. After the pedagogical skills there come the technical ones and finally the managerial ones. As far as the technical skills are concerned the research data indicate that the tutors (assistants, lecturers) are recent graduates of college and are already skilled with ICT, so no special training is needed in this direction. As far as the management is concerned, they do not seem to be a priority for Romania DL departments, being less addressed by the subjects participating in 
the research. A possible explanation is that many of the tasks of the tutor, in current practice, are handled by the administrative staff. Instead, the online department, both in Romania and abroad, the tutor is a manager of the course, the subjects pointing out that the way they organize the course from the very beginning depends the success of the course.

The training of teachers with the role of tutor at the university level, who can meet the needs of the implementation of the E-leaming system in Romania is more than a necessity, as declared by those who were surveyed. This training is closely linked to the availability of the teachers to use the Elearning, not to preclude resistance to change or not to treat the problem superficially. The optimism of the implementation of the E-learning is hindered by certain deductions of some teachers. These delays are translated into fear of change, uncertainty, adapting to new technology, which are sometimes justified. Instead, the attitude of the teachers who have skills in IT is different, they adapt more easily to this type of education. The training is a priority for the tutors outside Romania, courses being organized at the college / university level, for shorter periods or longer, online or blended leaming type. For Romania, both in terms of online self-instruction and short trainings, types of learning drawn from research, there are no tutorial training courses available at the national level, but according to ad hoc training needed (usually at a technical or managerial level).

The psycho-pedagogical module: It is interesting to notice that the main functions of the tutor - pedagogical, psycho-social, managerial and technical - found in the literature are the basis of the academic module for the tutors. The results of the present research confirm this reality, our subjects emphasizing the need for training the tutors in the areas directly converging with those functions. Thus, one possible way of academic training can be developed based on four pillars, namely teaching, psycho-social, managerial and technical. Also, a brief scan of 13 international courses on the elements that compose the training module features leads us to the four functions mentioned, and the pattern of comparative analysis conducted between ETT and AVLN courses, rounds out the picture. The figure below shows the factors taken into account in devising a possible way to the tutor training. 


\begin{tabular}{|c|c|c|}
\hline Lirerature & 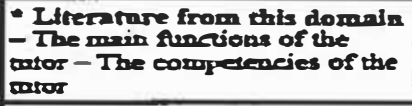 & 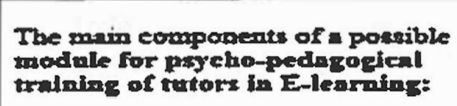 \\
\hline Resentel & 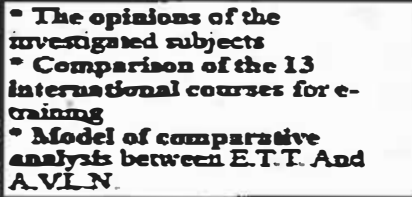 & $\begin{array}{l}\text { - Pedrgogienl Dimension } \\
\text { - Puyebo-Social Dimencian } \\
\text { - Manngarial Dimancion } \\
\text { - Technical Drmenrion }\end{array}$ \\
\hline
\end{tabular}

Figure 2. Factors that have contributed to the development of a possible mode of academic training for the tutor

The learning model which the distance learning in the universities participating in the investigation is based on is that of a distance education department within an existing institution. Such departments (Distance Learning) are affiliated with the traditional program units. Therefore, the university courses which are prepared by the teacher unit for the "daily" school-program are designed for both the students for the 'daily" program and those for DL. But the online courses (training departments from AVLN and ISE) are designed electronically, being used only for this type of education, not for the traditional one. At the Open University (Netherlands), Anadolu (Turkey) and University of the Philippines, the operating model of the faculty is the "stand alone", where the courses are designed only for distance learning, but the course materials and resources are designed electronically. These universities follow the model of the University Open University in England (Jalobeanu, 2001). It appears that the participating Romanian universities in the research follow a pattern similar to that of the foreign universities. Thus, for any form of DL learning, ODL or Online, the curriculum is similar to the traditional one, except that the course design is different, some being left in the traditional form, being posted on Elearning platform (National School, ESA), others are converted (translated) for online (OU / Netherlands, LLU / California, Anadolu / Turkey, Philippines) and others are specially designed for online, without passing through the filter of the traditional one (AVLN, ISE). From the previous listings (i.e. the universities participating in the research) it may be seen that some Romanian institutions adopt intemational practices related to the course design, while other institutions (ASE, SNSPA) are still dependent on the traditional education.

In the context of the aforementioned conclusions in the thesis we developed a method of psycho-pedagogical training of the tutors, structured on four dimensions (pedagogical, psycho-social, managerial and technical). On the one hand, the design of this module was based on the research of the literature. On the other hand, it took into account the information collected during the research, all organized in the four dimensions, in order to allow the results of the research to be organized in the form of a curriculum design, and the validation of the module. 


\subsection{The pedagogical dimension}

The investigation allowed us to highlight the need for initial evaluation of an E-learning course on the technical knowledge of the students and their learning styles. According to this evaluation the course can be designed, thus the leaning process being focused on the learners and not on the wishes and the possibilities of those who facilitate the learning.

According to the results of our study most students feel the need for a training at the technical and organizational level before the course starts. This is suggested by other authors (Paloff \& Pratt, 2007; Curiskis-Johnson, 2007). Most students felt the need to investigate the introduction of e-learning atmosphere in order not to be surprised by the elements that might disturb them in the learning process.

For the students interviewed the tutor must be present in the leaming process both in the beginning of the course (by clarifying the requirements of the course, providing resources, bibliography), during the course (through feedback given to the student, identifying the positive / negative student activities, constructive explanations) and in the final phase (through support of academic preparation for the exam).

The choice for the learning methods, activities and the assessment, depending on students' learning styles, is a necessity for the students participating in the study. Although it is a greater effort from the part of the tutor to provide a wider range of activities, the differentiated treatment of students is emphasized by the students, stressing that, they, by this attitude, follow the student centred learning principles.

Group activities (like projects in pairs, in groups) is a problem for the students in Romania who participated in the research. The lack of involvement in such activities is motivated by the unsynchronized timetable regarding the group activities or the lack of time for the individual preparation for the course. Thus, for the students investigated in Romania, their first priority is the individual activities, and then the group activities.

The students' opinions on the use of the portfolio as a means of evaluation were divided, varying between total refusal, on the grounds that other people can write in your personal portfolio, to positive acceptance, the latter holding that an assessment through a portfolio avoids routine and conformity. Using the feedback provided by the course colleagues, self-tests, personal journals, the blogs, portfolios, essays, the students are invited to a qualitative assessment, but not all students interviewed agree with only this type of assessment. The research findings highlighted the need to combine both types of qualitative assessment and quantitative (computer-assisted tests, papers). 


\subsection{The Psycho-Social Dimension}

Generally, the students in the E-learning system, participants in this study, need encouragement, guidance, feed-back from the part of the tutor in the learning process. Such students need encouragement and motivation by engaging them in group activities. The open and creative questions motivats the online students to communicate, and they in turn will be open with the tutor, but also with the colleagues. The quality feedback provided in time is another way to determine the students to be involved in education. Thus, learning in the E-learning environment encourages the formation of self-taught in students, but under no circumstances can we speak about the lack of the tutor in the learning process, because the lack of contact between the institution and students lead to a kind of robotization of the leaming system. The students are not learned to communicate with the media (TV, radio, computer, DVD), but they communicate through these technologies with a person and that person is the tutor.

The created virtual community offers a wide choice of knowledge, learning, for both the tutor and the student. Thus, it was found that learning from students in the educational process is a sign of professional maturity, given that some students are quite literate in some areas, one reason being that of accessing information online. In turn, the students learn from their peers or tutors.

From the perspective of the Romanian students interviewed, the participants in a DL course, usually have to wait a long time to receive feedback from the tutor, and when feedback is given, reference is made to the group, not individually. It is different in the online environment where the presence of each participant student is valued.

\subsection{The Managerial Dimension}

From the results of the research there came the idea that the key elements for meeting and providing tutorial explanations, encouraging and motivating students, monitoring the progress of leaming are present in most institutions participating in e-learning, but in a lesser extent in the Romanian institutions investigated. A possible explanation is the existence of tutorial meetings which do not have well established rules regarding the learning process, and also the existence of an insufficient number of tutors needed for the training of the students. As a consequence, there is an irregular feedback given to the students and their low participation in group projects.

\subsection{The technical Dimension}

Although the investigated tutors have not given a major importance to this field, our research has shown that it is not possible to deploy an e-learning 
course without technology. Thus, the institutions participating in this study used a wide range of technologies, mostly used in Romania, such as:

Discussion forum: a) for online discussions (asynchronous, synchronous), b) for socializing (asynchronous), c) for frequently asked questions (asynchronous)

Power Point presentation (both synchronous / asynchronous - files);

e-mail used for: a) personal feedback, b) feedback from the colleagues;

Internet and computer (files) used in: a) search for online materials, b) individual research, c) group research, d) online presentation (video / audio), e) $\mathrm{TV} /$ radio converted into video / audio files, f) case study presentations via you tube;

Interactive chat: a) collaboration with the colleagues b) communication during the course;

DVDs used for: a) documentaries, b) films, c) experiments, d) case studies;

virtual library: a) books in (pdf) format, b) courses adapted for the online learning.

In conclusion, we can state that the research made allows us to have a clearer picture of the tutorship activity in the Romanian system of learning and to write down the pillars of a training module for e-tutors in Romania. The comparison of the tutors' work in Romania to other countries participating in the research has helped us to understand what are the points that can be improved in the Romanian E-learning and tutoring systems. As future research we intend to validate the pillars of the training course for online tutors in Romania by giving a pilot course there.

\section{REFERENCES:}

1. CURISKIS-JOHNSON, N. (2007). Pre-registration for online Courses. In: MERLOT Journal of Online Learning and Teaching, No. 3(2);

2. DE VOS, S.H., FOUCHE C.B, DELPORT C.S.L., (2002). Research at grass roots. South Africa: Van Schaik;

3. DENIS, B., WATLAND, P., PIROTTE, S., VERDAY, N. (2004). Roles and Competencies of the e-Tutor. Networked Learning Conference, Retrieved on July 10, 2011, from: ttp://www.networkedlearningconference.org.uk

4. DUGGLEBY, J. (2000). How to be an online tutor. England: Gower Publishing Limited;

5. GARRISON D.R., ANDERSON T. (2003). E-learning in the 21st Century. London: Routledge Falmer;

6. ISTRATE, O. (2000). Educatia la Distanłă - Proiectarea materialelor. Botoşani: Agata. 
7. JALOBEANU, M. Învătământul la distantă şi instruirea prin Internet. Istorie, evolutie, estimäri, Retrived on July 9, 2011, from: jalobean.itimcj.ro/Wbdl.html

8. LEVY, P. (1999). Cibercultura. San Paulo: Editora 34, Retrieved on July 10, 201 1, from: http://www.scribd.com/doc/1 1036046/Cibercultura-Pierre-Levy 9. MATU, S.T., CRISTEA. V., UDREA, O. (2005). Intelligent Systems for Web Instruction. Bucharest: Polytechnic Press;

10. MCKENZIE, J. (2000). Enriching Content Teaching through Long Term Process Based Relationships for Online Learning Support, Case Study from Online Tutoring E-Book, Retrieved on June 25, 2006, from: otis.scotcit.ac.uk/casestudy/mckenzie-b.doc

11. PALLOF, R., PRATT, K. (2007). Building Online Learning Communities. $2^{\text {nd }}$ Edition. San Francisco: Jossey-Bass.

12. PETERS, O. (2001). Learning and Teaching in Distance Education, London: Kogan Page;

13. RYAN S., SCOTT, B. FREEMAN H, PATEL D. (2000). The Virtual university, London: Kogan Page;

14. SALMON, G. (2000). E-moderating. London: Kogan Page.

15. SINGER, M., SARIVAN, L. (2006). Quo Vadis Academia, Repere pentru o reformă de profunzime in invătământul superior. Bucureşti: Sigma.

16. SPECTOR, J. M. (2001). Competencies for online teaching, Eric Digest, Retrieved on June 21, 2007, from: http://www.ericdigests.org/20022/teaching.htm.

17. THENG, J. THIMBLEY, H. (1998). Addressing Design and usability issues in Hypertext and on the World Wide Web by re-examining the Lost in Hyperspace Problem. In Journal of Universal Computer Science, 4(11), 839855.

18. *** Legea $n r 128$ din 12 iulie 1997 privind statutul personalului didactic (retrived from: www.edu.ro/index.php?module=uploads\&func.fileld). 